\title{
Competitiveness in Dairy Trade - the Case of EU and the Visegrad Group Countries
}

\author{
Judit Nagy, Zsófia Jámbor \\ Corvinus University of Budapest, Hungary
}

\begin{abstract}
The European Union (EU) produces $15 \%$ of its agricultural production in the dairy industry. The article focuses on the European Union and Visegrad Group's (VG) dairy export and analyses it with Balassa's (Revealed Comparative Advantage, RCA) index. Our aim is to explore the foundations of EU's competitiveness and the role and opportunities of the dairy sector in VG countries.

The analysis is based on EU dairy export data for the period 2000-2017. The main result of the analysis is that the most competitive countries in terms of export performance (Denmark, France, Ireland and Belgium) do not fully align with the order of the largest dairy producing and processing countries (Germany, France, the United Kingdom, the Netherlands) or the largest dairy exporters (Germany, the Netherlands, France and Belgium). We have discovered that some EU countries have a really strong, dominant competitive advantage. The reason for this is that the highest customer value can be achieved through the production of highly processed products, and the most competitive countries specialize in the production of one or a few of these products.
\end{abstract}

\section{Keywords}

Dairy industry, revealed comparative advantage, export, competitiveness.

Nagy, J. and Jámbor, Z. (2019) "Competitiveness in Dairy Trade - the Case of EU and the Visegrad Group Countries", AGRIS on-line Papers in Economics and Informatics, Vol. 11, No. 4, pp. 61-74. ISSN 1804-1930. DOI 10.7160/aol.2019.110406.

\section{Introduction}

170 million tons of milk is produced in the EU annually, and 45 tons of processed dairy product is sold to consumers. $87 \%$ of dairy products produced in the EU are delivered to consumers within the EU (Lemoine, 2016; Bojnec and Ferto, 2014). In world trade, dairy products represent a low proportion, as typically produced and processed goods are consumed within the country, but their share of consumption is steadily increasing with the expansion of a healthy lifestyle and their role is expected to continue to grow further. The biggest annual growth is expected in developing countries, India and China (4-5\%), while the developed world expects only $0.8-1 \%$ growth in the coming decades (OECD-FAO, 2018). In order to increase EU competitiveness, achieving economies of scale, high value-added products and innovation, as well as knowledge accumulation play key roles (Poppe, 2008). Since the paper analyses the competitiveness of dairy trade, it is important to discuss the concept of competitiveness, the specifications of dairy trade and the factors influencing the competitiveness in dairy industry.

\section{Interpretation of competitiveness}

There are several approaches and definitions for interpreting competitiveness. The levels of competitiveness are most often interpreted as micro, mezo and macro competitiveness. The micro-level interpretation examines competitiveness at the level of the corporate sphere, which can be defined as: "the ability of a company to produce products or services that customers prefer more to buy than those of their competitors" (Wijnands et al., 2008, 3). According to Domazet $(2012,294-295)$, competitiveness is the ability of a company to "produce products that meet the requirements of the open market in a continuous and profitable manner, with prices, quality, etc. respect".

Mezo-level competitiveness can be interpreted at a regional level, according to Kitson et al. (2004, 992). Gorton et al. $(2013,4)$ use a different approach to understand the competitiveness of a region because they believe that its task is 
to "provide an attractive and sustainable environment for companies and residents in both life and work". Therefore, mezo-level competitiveness is located between the micro and the macro level, but it can be determined neither by the aggregate competitiveness of companies operating in a particular geographical area nor by dividing a country's competitiveness (Budd and Hirmis, 2004). According to the latter authors, regional competitiveness is a complex concept that includes the labour market situation, transport costs, the size of companies operating there, the intensity of research and development, innovation capacity and export capacity. Bristow (2005) argues that it is not enough to examine the prosperity of a region in order to judge the competitiveness of it but to understand the factors that determine the sustainable macroeconomic performance of the region.

Macro-levelcompetitiveness, i.e. the competitiveness of nations, according to Chikán (2008), denotes the ability of a national economy to ensure and increase the well-being of its citizens in the course of its operations, with the sustainable growth of production factors. This ability is manifested in creating an environment for companies and other institutions that can create, use, and sell products and services that meet the requirements of global competition and changing social standards.

According to Porter (1990), the competitiveness of a nation is based on four interrelated factors (diamond model): factor (input) conditions, demand conditions, supporting and related industries, and corporate strategy, structure and competition. Factor conditions include the available workforce, the quality and quantity of local ingredients, and all the factors that are essential for efficient production. Demand conditions refer to the peculiarities of the demand of the local market for the final product, which may be so complex that companies have to rise to the standard. Supporting and related industries that are globally competitive provide a stable and reliable background for manufacturing industries, which can also be a source of costeffectiveness, high-quality inputs and innovative ideas. Corporate strategy, structure and competition can also affect a nation's competitiveness. National circumstances determine how the company is founded, traditions define the style of leadership, and domestic rivalry suggests that companies need to be cost-effective, innovative and customeroriented. Domestic competition can be even greater if the geographical concentration is high.
The first economists who dealt with the theory of commerce at the national level sought to answer why the different nations were trading with each other. Among the answers to this question, the most cited is Ricardo's (1817) theory of comparative advantages which says that countries should focus on producing goods with comparative advantages.

Based on the theory of comparative advantages of Ricardo, Balassa created an index (Balassa index) (1965), which is used to measure comparative advantages. However, there are many different methods to measure competitiveness, just to mention the indices of the World Economic Forum and the World Bank. As the study focuses on trade-based macro-competitiveness, we have chosen the Balassa index, which is able to capture competitiveness through commercial processes.

Many researches use the theory of comparative advantage to characterize international trade in various industries: Saricoban and Kaya (2017) in seafood, Leishman et al. (2000) in wool and Torok et al. (2018) in coffee export, and now we apply it to dairy industry.

\section{Dairy industry in EU and Visegrad Group countries}

The food industry is a significant sector in $\mathrm{VG}$, representing $3.8 \%$ of GDP combined with agriculture as well as employing $12.5 \%$ workers. EU accession has had a positive impact on the foreign trade of all four countries. Polish agricultural exports have doubled, Czech and Slovakian have increased by $83 \%$ and the Hungarian by $23 \%$ between 2003 and 2006 . Milk products ranked high among the main export products of Poland and the Czech Republic, and they accounted for 20 per cent of Slovakian agricultural exports. Hungary is rather a net importer of dairy products (Kiss, 2007).

In Europe, 170 million tons of milk is produced annually and 45 million tons of fresh dairy products are consumed (Lemoine, 2016). According to Eurostat data, in 2016, one-fifth of the milk produced came from Germany, another $16 \%$ from France, $10 \%$ to $10 \%$ from the UK and the Netherlands (Eurostat, 2017).

Forecasts say that a $1 \%$ annual growth in production was expected in Europe in the medium term. The market is heavily influenced by the preferences of the consumers, i.e. the preferences of processed products (the consumption of milk is constantly decreasing), structural changes (e.g. organic production, environmental aspects), but these 
often pose a challenge to producers (European Commission, 2017 and 2018).

The EU accounts for one quarter of the world's dairy production and $30 \%$ of its commercial growth, mainly with highly processed products (cheese, milk powder, butter) (OECD-FAO, 2018). Behind this, the main competitors have been able to increase their production to a greater extent, so European countries are entering the market with highly processed products: nearly half of the world's cheese is made in Europe. In addition, marketing and product innovation opportunities are important: new products, new flavours, new ingredients appear on the market (Tacken et al., 2009; Lemoine, 2016 and Jansik et al., 2014).

In Visegrad Group regional dairy sector faces many difficulties. One of these is the abolition of the milk quota system, which favours more efficient and competitive farming. As Salou (2017) points out, an elementary pillar of the Common Agricultural Policy was abolished on $1^{\text {st }}$ April 2015. The measure expects growth in competitiveness and market orientation of the industry. In addition to the increase in domestic supply due to the end of the quota system, the introduction of the Russian embargo and the appearance of cheap imported dairy products also had a negative effect: prices dropped significantly (Zdráhal et al., 2016; Zdráhal et al., 2018 Hanisch et al., 2013). The industry is also significantly influenced by local consumer habits, the rapidly deteriorating, difficult-totransport products are therefore mainly consumed locally. Another critical issue is the development of technology to reduce production costs.

The dairy industry in Hungary can be characterized as oligopsonistic (Čehura et al., 2015). It is moderately concentrated, the sector is dominated by small individual and large industrial dairy farms (Bakucs et al., 2012). In general, the sector's strategic focus is to increase competitiveness and efficiency, and to halt and stabilize the decline in current livestock, and to increase the value of milk content (particularly fat). Another important goal is to get more raw milk for processing in Hungary and not to export as a low value-added product. The dairy trade is characterized by exports of raw milk and imports of processed products, but the proportions are improving (Perekhozhuk et al., 2013).

In the Czech Republic, the dairy industry is responsible for the $17 \%$ of sales and $10 \%$ of employers in the food industry. Czech dairy producers face with low profitability and a high debt-to-equity ratio (Spicka, 2013). Spicka et al.
(2015) consider vertical integration, innovation, and technological improvement as the main focuses of development of the sector. The industry structure is oligopolistic, slightly concentrated with relatively low entry barriers, which allows to small producers to enter a local market and sell their milk and processed products there (Spicka, 2013).

Kubicova et al. (2014) report on concentration in Slovak dairy industry. Plenty of foreign companies entered the market and carried out modernization and economically stabilized the dairy sector. Food expenditure is at the top of household consumption which of dairy is the second one. However, Slovakia significantly lags the other EU member states in dairy consumption.

Bakucs et al. (2012) described the Polish dairy industry as a successful sector within the food industry. $95 \%$ of milk is produced by family farms and concentration is very low. The share of foreign companies on the market is also low $(10 \%)$ in comparison with the regional standard. Modernization has been carried out, not only in product assortment and production technology but also in marketing channels (Fałkowski, 2012).

\section{Competitiveness in dairy industry}

The dairy industry is a significant sector of the manufacturing industry, with strong competition between players on both national and international markets. The competitiveness of the dairy industry in a country is largely determined by the structure of the industry, the number, size and geographical distribution of competitors, the level of ownership structure and the cost of production resources (Jansik et al., 2014; Viira et al., 2015 and Zdráhal et al., 2018), which is almost identical to Porter's (1990) theory. The competitiveness of the dairy industry can also be measured through market performance, which should be distinguished in two directions: domestic demand and exports (Bojnec and Ferto, 2014). The stability of market positions occupied by companies in the domestic market predicts the ability to compete with imports in both price and product range. Generally speaking, the larger internal market allows companies to achieve economies of scale and financial stability, which increases the likelihood of foreign market success (Jansik et al., 2014). Smaller dairy companies in smaller countries are constantly struggling to achieve economies of scale, which either intensify competition and lead to high concentration on the market or force operators to export. 
Many studies have already dealt with comparative advantages in the dairy industry, but focusing on specific countries or regions and having a different interest. Jansik et al. (2014) investigated the dairy chains in Northern Europe and found that the region has had a positive foreign trade balance for its products for a long time, due to the significant modernization and the shift to high value-added products from mass production. With the expansion of the EU (with the Baltic States), consumption in the region also increased significantly. In 2009, Jansik compared the Finnish and Baltic dairy industry with the Balassa index. The four countries have shown a lot of similarities, all of them are net dairy exporters, but the ownership structure of the dairy chain determines the performance of a country. Examining the competitiveness of the Estonian dairy industry, Viira et al. (2015) found that its keys are the high milk yield and the large farm size, which makes it possible to reduce transportation costs. At the same time, attention was drawn to the fact that a small country specializes in a product and its strong dependence on the markets of the neighbouring countries, is a big risk. Tacken et al. (2009) found that the region is a significant, innovative player on the world market when they examined the competitiveness of the EU dairy industry, but the market is growing faster than the region's exports and therefore it is losing ground.

The article aims to contribute to the development of literature in three ways. On the one hand, the RCA model is applied to a regionally and globally important sector. On the other hand, due to the spread of healthy lifestyles, the products analysed are of great importance in developed economies and dynamic growth is expected in developing regions. Third, the study intends to identify the factors behind the comparative advantage of countries.

The article is structured according to the following structure. After introducing the relevant literature, we reveal the methodology we used to analyse the competitiveness of dairy industry. Then we show the most important results obtained by statistical analysis of dairy trade data. This is followed by an evaluation of the comparative advantage patterns. Finally, the final conclusions and possible directions for future research will be formulated.

\section{Materials and methods}

In this chapter, we introduce the theoretical model we have used for the analysis measuring the competitiveness of VG countries in dairy industry. We also provide description on the data we used and descriptive statistics to highlight tendencies.

\section{The Revealed Comparative Advantage Index}

The focus of our current study is related to the revealed comparative advantage index (RCA) which was elaborated and reported primarily by Balassa in 1965. The RCA index is to be understood as follows:

$\mathrm{RCA}_{\mathrm{ij}}=\left(\frac{X_{i j}}{X_{i t}}\right) /\left(\frac{X_{n j}}{X_{n t}}\right)$

where $X$ indicates export, $i$ means a given country, $j$ is a given product, $t$ is a group of products and $n$ is for a group of countries. According to this, the index can be calculated by dividing a given country's export share of its total exports with the export share in total exports of a reference group of countries. After this calculation the result is to be interpreted as follows. The RCA index higher than 1 means that the examined country has a comparative advantage compared to the reference countries and in case the RCA index is equal or less than 1 , a revealed comparative disadvantage exists.

The original index is criticised for various reasons. One of the reasons is that in the case of many products, a country can be exporter and importer as well (Buckley et al., 1988). Another reason is the index's asymmetry to zero. The problem of asymmetric values comes from the fact that RCA index implies revealed comparative disadvantage between 0 and 1 and advantage above 1, respectively, thereby overestimating a sector's relative weight (Vollrath, 1991; Laursen, 2015). The index neglects the various effects of economic policies, however government intervention, and especially protectionist policies highly affect international trade and associated markets, the impact of which is not measured by the RCA index.

Researchers tried to handle the above-mentioned problems, mainly the symmetry of the index. Vollrath (1991) proposed three different specifications of comparative advantage. First, he created the revealed import advantage index (RMA), replacing export values with import ones in the original index as follows:

$\mathrm{RMA}_{\mathrm{ij}}=\left(\frac{M_{i j}}{M_{i t}}\right) /\left(\frac{M_{n j}}{M_{n t}}\right)$

Compared to the RCA index, RMA values below one mean comparative advantage, thereby clearing up the problem of asymmetry. The second index 
suggested by Vollrath (1991) is the revealed trade advantage index (RTA), which is a simple conversion of the first and the second equations (in this case, $\mathrm{RXA}_{\mathrm{ij}}$ is the same as the original RCA index of Balassa, since it contains only export data):

$$
\mathrm{RTA}_{\mathrm{ij}}=\mathrm{RXA}_{\mathrm{ij}}-\mathrm{RMA}_{\mathrm{ij}}
$$

Positive values here mean comparative advantage, while negatives mean disadvantage. Third, Vollrath (1991) also implemented the revealed competitiveness index (RC) by taking the natural log of the RXA and RMA indices as follows:

$$
\mathrm{RC}_{\mathrm{ij}}=\ln \mathrm{RXA}_{\mathrm{j}} \mathrm{j}-\ln \mathrm{RMA}_{\mathrm{ij}}
$$

The $\mathrm{RC}$ index is symmetric to zero and positive values mean revealed competitiveness.

Dalum at al., (1998) also tried to solve the asymmetric value problem of the original Balassa-index and created the Revealed Symmetric Comparative Advantage (RSCA) index:

$R S C A=(B-1) /(B+1)$

The RSCA takes values between -1 and 1 , where positive values indicate a comparative export advantage, and values between -1 and 0 , a comparative export disadvantage. According to Laursen (2015) RSCA is better than RCA and RC because it can be defined even if the export is 0 in case of a product or a sector.

According to existing literature (Hinloopen and Marrewijk, 2001; Saricoban and Kaya, 2017) RCA indices can be classified into four different groups to measure the strength of comparative advantage of a given country. These four groups are as follows (Table 1):

\begin{tabular}{|l|l|l|}
\hline Classification & \multicolumn{1}{|c|}{ RCA index } & \multicolumn{1}{c|}{ Description } \\
\hline Group 1 & $0<\mathrm{RCA} \leq 1$ & $\begin{array}{l}\text { Comparative disadvantage } \\
\text { of given country exists. }\end{array}$ \\
\hline Group 2 & $1<\mathrm{RCA} \leq 2$ & $\begin{array}{l}\text { Weak comparative advantage } \\
\text { of given country exists. }\end{array}$ \\
\hline Group 3 & $2<\mathrm{RCA} \leq 4$ & $\begin{array}{l}\text { Medium level comparative } \\
\text { advantage of given country } \\
\text { exists. }\end{array}$ \\
\hline Group 4 & $4<\mathrm{RCA}$ & $\begin{array}{l}\text { High level comparative } \\
\text { advantage of given country } \\
\text { exists. }\end{array}$ \\
\hline
\end{tabular}

Source: based on Hinloopen and Marrewijk, 2001 and Saricoban and Kaya, 2017

Table 1: Classification of RCA indices.

The research was performed based on the European Union dairy trade data, downloaded from the World Bank's World Integrated Trade Solution (WITS) database. Data were retrieved from the HS-6 level for above-mentioned countries from 2000 to 2017 for all dairy products. The next sections uncover our results.

\section{Descriptive statistics}

In order to find the top performers within EU28, average export values have been calculated between 2000 and 2017 for three time periods for all EU members. Note that the so-called intra-export trade values have been calculated, the export values of a given country within EU borders. It is also important to see that the selected time periods do not follow the exact accession years of the EU members. As visible on Table 1, the Top 10 exporter countries of the EU28 within the dairy industry have together a high concentration ratio $(90.5 \%, 87.2 \%$ and $91 \%$ in the three time periods). The top performers are traditionally Germany, Netherlands and France, these three EU members own more than 50\% from the intra-export shares within the dairy industry. VG occupies a solid position with less than $8 \%$ export value performance between 2012 and 2017 (Table 2). From the below list it is worth mentioning Poland, the only one being VG country and occupying a place within the Top 10 performers. Based on above-mentioned export concentration results, we decided to study the competitiveness of the Top 10 EU exporter countries plus VG in more details.

On product level it is observable that four products are leading the export market shares within the EU (Figure 1): cheese (40690, with almost one third of the total export volume), fresh cheese (40610, with $11 \%$ ), butter (40500, with $10.7 \%$ ) and milk (40120, with $10.5 \%$ ). The distribution of the products seems to maintain a quite constant position however, the total export volume is showing an increasing tendency. The detailed description of the product codes can be found in the Appendix 1.

As to EU dairy industry imports, a lower concentration ration can be observed $(82.5 \%, 77.2 \%$ and $80.1 \%$ ) in the three consecutive periods. As visible on Table 4 the concentration of import values within the top importers is more balanced, Germany and Italy occupy the first two places, Belgium, Netherlands, the United Kingdom and France own similar import volumes within the EU. VG is again obtaining a solid place with around $6.4 \%$ import volume, as it can be seen in Table 5.

Regarding the export and import data of $\mathrm{VG}$ countries, one can see that Poland and the Czech Republic are net exporters, while Slovakia 


\begin{tabular}{|l|c|c|c|c|c|c|}
\hline \multirow{2}{*}{ Country } & \multicolumn{2}{|c|}{$\mathbf{2 0 0 0} \mathbf{2 0 0 5}$} & \multicolumn{2}{c|}{$\mathbf{2 0 0 6}-\mathbf{2 0 1 1}$} & \multicolumn{2}{c|}{$\mathbf{2 0 1 2 - 2 0 1 7}$} \\
& EX value & $\mathbf{\%}$ & EX value & $\mathbf{\%}$ & EX value & \% \\
\hline Germany & 4353299 & $24.1 \%$ & 7544942 & $23.6 \%$ & 8250854 & $24.0 \%$ \\
\hline Netherlands & 2727854 & $15.1 \%$ & 4358132 & $13.6 \%$ & 5479209 & $15.9 \%$ \\
\hline France & 3165138 & $17.5 \%$ & 5227206 & $16.3 \%$ & 5298903 & $15.4 \%$ \\
\hline Belgium & 1686882 & $9.3 \%$ & 2556782 & $8.0 \%$ & 2907799 & $8.4 \%$ \\
\hline Italy & 836030 & $4.6 \%$ & 1636039 & $5.1 \%$ & 2233209 & $6.5 \%$ \\
\hline Ireland & 904080 & $5.0 \%$ & 1522021 & $4.8 \%$ & 1655563 & $4.8 \%$ \\
\hline Denmark & 980409 & $5.4 \%$ & 1569584 & $4.9 \%$ & 1587249 & $4.6 \%$ \\
\hline Poland & 287549 & $1.6 \%$ & 1164796 & $3.6 \%$ & 1388714 & $4.0 \%$ \\
\hline United Kingdom & 759368 & $4.2 \%$ & 1172683 & $3.7 \%$ & 1380236 & $4.0 \%$ \\
\hline Austria & 643477 & $3.6 \%$ & 1146324 & $3.6 \%$ & 1160190 & $3.4 \%$ \\
\hline EU28 total & 18066667 & $100.0 \%$ & 31983333 & $100.0 \%$ & 34433333 & $100.0 \%$ \\
\hline $\begin{array}{l}\text { Concentration } \\
\text { (of the top 10) }\end{array}$ & & $\mathbf{9 0 . 5} \%$ & & $\mathbf{8 7 . 2} \%$ & & $\mathbf{9 1 . 0} \%$ \\
\hline
\end{tabular}

Note: Countries are listed in decreasing order based on their 2012-2017 averages Source: Based on own calculations on WITS (2018)

Table 2: Top 10 exporter countries of the EU between 2000 and 2017 (Export values in 1000 US\$) in dairy industry.

\begin{tabular}{|l|c|c|c|c|c|c|}
\hline \multirow{2}{*}{ Country } & \multicolumn{2}{|c|}{$\mathbf{2 0 0 0 - 2 0 0 5}$} & \multicolumn{2}{c|}{$\mathbf{2 0 0 6 - 2 0 1 1}$} & \multicolumn{2}{c|}{$\mathbf{2 0 1 2 - 2 0 1 7}$} \\
\hline Poland & EX value & $\mathbf{\%}$ & EX value & $\mathbf{\%}$ & EX value & \% \\
\hline Czech Republic & 287549 & $1.6 \%$ & 1164796 & $3.6 \%$ & 1388714 & $4.0 \%$ \\
\hline Slovakia & 163663 & $0.9 \%$ & 649578 & $2.0 \%$ & 738366 & $2.1 \%$ \\
\hline Hungary & 99599 & $0.6 \%$ & 332085 & $1.0 \%$ & 335814 & $1.0 \%$ \\
\hline $\begin{array}{l}\text { VG total and } \\
\text { concentration } \\
\text { (of the VG) }\end{array}$ & 35705 & $0.2 \%$ & 166060 & $0.5 \%$ & 244366 & $0.7 \%$ \\
\hline
\end{tabular}

Note: Countries are listed in decreasing order based on their 2012-2017 averages

Source: Based on own calculations on WITS (2018)

Table 3: VG countries between 2000 and 2017 (Export values in 1000 US\$) in dairy industry.

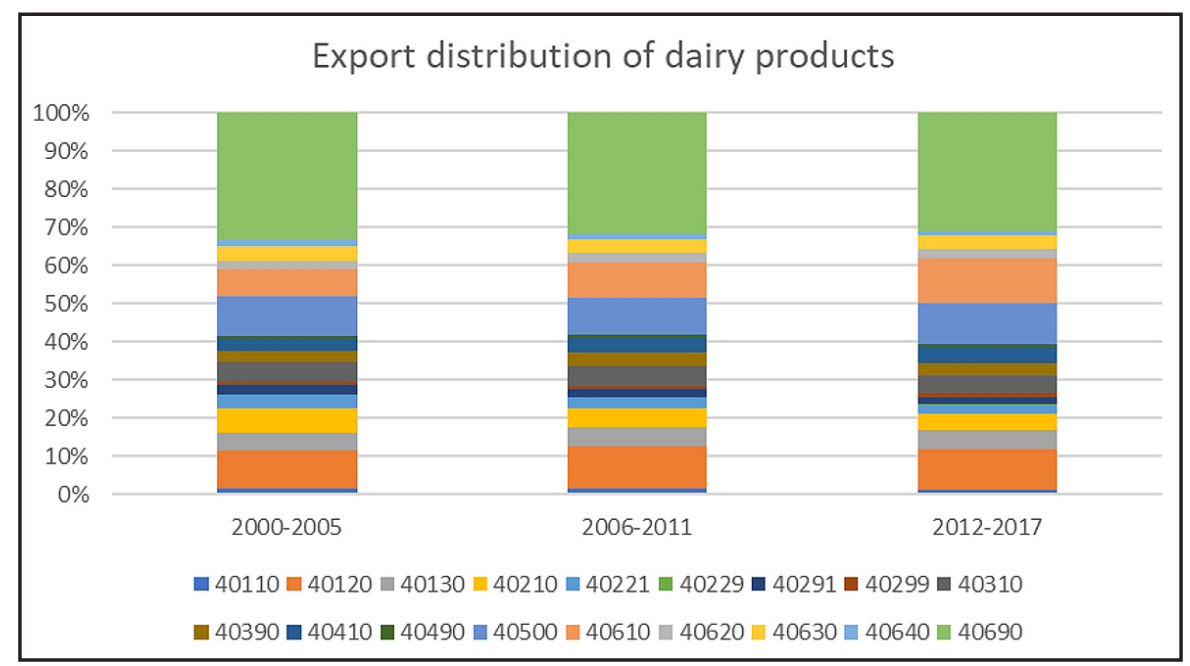

Note: See detailed product codes and its descriptions in the Appendix.

Source: Own calculations based on WITS (2018) data

Figure 1. Export distribution of dairy products within EU between 2000-2017. 


\begin{tabular}{|c|c|c|c|c|c|c|}
\hline \multirow{2}{*}{ Country } & \multicolumn{2}{|c|}{$2000-2005$} & \multicolumn{2}{|c|}{$2006-2011$} & \multicolumn{2}{|c|}{$2012-2017$} \\
\hline & IM value & $\%$ & IM value & $\%$ & IM value & $\%$ \\
\hline Germany & 3390992 & $18.6 \%$ & 5849751 & $18.4 \%$ & 6520851 & $18.8 \%$ \\
\hline Italy & 2723832 & $14.9 \%$ & 4249990 & $13.4 \%$ & 4207822 & $12.1 \%$ \\
\hline Belgium & 2156478 & $11.8 \%$ & 3171240 & $10.0 \%$ & 3605880 & $10.4 \%$ \\
\hline Netherlands & 1853440 & $10.1 \%$ & 2884482 & $9.1 \%$ & 3600988 & $10.4 \%$ \\
\hline United Kingdom & 2017794 & $11.0 \%$ & 3288210 & $10.4 \%$ & 3591909 & $10.4 \%$ \\
\hline France & 1920886 & $10.5 \%$ & 3046680 & $9.6 \%$ & 3486555 & $10.1 \%$ \\
\hline Austria & 376914 & $2.1 \%$ & 686184 & $2.2 \%$ & 821716 & $2.4 \%$ \\
\hline Poland & 58477 & $0.3 \%$ & 388868 & $1.2 \%$ & 817209 & $2.4 \%$ \\
\hline Denmark & 296359 & $1.6 \%$ & 493270 & $1.6 \%$ & 589913 & $1.7 \%$ \\
\hline Ireland & 283905 & $1.6 \%$ & 451969 & $1.4 \%$ & 524214 & $1.5 \%$ \\
\hline EU28 total & 18266667 & $100.0 \%$ & 31766667 & $100.0 \%$ & 34683333 & $100.0 \%$ \\
\hline $\begin{array}{l}\text { Concentration } \\
\text { (of the top 10) }\end{array}$ & & $82.5 \%$ & & $77.2 \%$ & & $80.1 \%$ \\
\hline
\end{tabular}

Note: Countries are listed in decreasing order based on their 2012-2017 averages Source: Based on own calculations on WITS (2018)

Table 4. Top 10 importer countries of the EU between 2000 and 2017 (Import values in 1000 US\$) in dairy industry.

\begin{tabular}{|c|c|c|c|c|c|c|}
\hline \multirow{2}{*}{ Country } & \multicolumn{2}{|c|}{$2000-2005$} & \multicolumn{2}{|c|}{$2006-2011$} & \multicolumn{2}{|c|}{$2012-2017$} \\
\hline & IM value & $\%$ & IM value & $\%$. & IM value & $\%$ \\
\hline Poland & 287549 & $1.6 \%$ & 1164796 & $3.6 \%$ & 1388714 & $4.0 \%$ \\
\hline Czech Republic & 163663 & $0.9 \%$ & 649578 & $2.0 \%$ & 738366 & $2.1 \%$ \\
\hline Slovakia & 99599 & $0.6 \%$ & 332085 & $1.0 \%$ & 335814 & $1.0 \%$ \\
\hline Hungary & 35705 & $0.2 \%$ & 166060 & $0.5 \%$ & 244366 & $0.7 \%$ \\
\hline $\begin{array}{l}\text { VG total and } \\
\text { concentration } \\
\text { (of the VG) }\end{array}$ & 586516 & $3.2 \%$ & 2312519 & $7.2 \%$ & 2707260 & $7.9 \%$ \\
\hline
\end{tabular}

Note: Countries are listed in decreasing order based on their 2012-2017 averages

Source: Based on own calculations on WITS (2018)

Table 5. VG countries between 2000 and 2017 (Import values in 1000 US\$) in dairy industry.

and Hungary are rather net importers. It is also interesting, that although the Czech Republic, Slovakia and Hungary are similar size countries in terms of area, GDP/capita and population, the Czech's export and import is almost double of the latter two countries' performance.

\section{Results and discussion}

\section{Analysis of comparative advantages}

After the descriptive statistics, in this section, the different comparative advantage indices calculated for the selected 9+4 EU members will be presented for the same time period comparing their results.

Table 6 is showing the original Balassa indices for the selected 13 countries (top 10 EU dairy product exporters and VG) calculated for the period between 2000-2017. As visible on the table, Denmark, France and Ireland have the highest revealed comparative advantages, compared to other countries, but Belgium, Austria, Netherlands and Poland also possess comparative advantages. On the other side, Germany, United Kingdom, Italy, Czech Republic, Slovak Republic have revealed comparative disadvantages, and so has Hungary with a lowest Balassa index (0.29) result. Comparing the VG countries, only Poland possesses comparative advantage within the members for the given time period.

Applying Hinloopen and Marrwijk's (2001) and Saricoban and Kaya's (2017 classification, in our analysis, none of the analysed countries has a high-level comparative advantage and only Denmark achieved a medium level comparative advantage. Some other countries (France, Ireland, Belgium, Austria, Netherlands and Poland) have weak comparative advantages.

To get a whole picture, the following indices also have been calculated: revealed trade advantages 


\begin{tabular}{|l|c|c|c|c|}
\hline Country & $\mathbf{2 0 0 0 - 2 0 0 5}$ & $\mathbf{2 0 0 6 - 2 0 1 1}$ & $\mathbf{2 0 1 2 - 2 0 1 7}$ & $\mathbf{2 0 0 0 - 2 0 1 7}$ \\
\hline Germany & 0.98 & 0.93 & 0.88 & 0.93 \\
\hline Netherlands & 1.21 & 1.08 & 1.29 & 1.19 \\
\hline France & 1.48 & 1.67 & 1.73 & 1.62 \\
\hline Belgium & 1.39 & 1.21 & 1.35 & 1.32 \\
\hline Italy & 0.46 & 0.52 & 0.64 & 0.54 \\
\hline Denmark & 2.56 & 2.13 & 2.02 & 2.2 \\
\hline Poland & 0.72 & 1.24 & 1.03 & 1.00 \\
\hline Ireland & 1.25 & 1.54 & 1.43 & 1.41 \\
\hline United Kingdom & 0.56 & 0.55 & 0.55 & 0.55 \\
\hline Austria & 1.33 & 1.15 & 1.09 & 1.20 \\
\hline Czech Republic & 0.93 & 0.85 & 0.82 & 0.87 \\
\hline Slovakia & 0.82 & 0.80 & 0.56 & 0.72 \\
\hline Hungary & 0.12 & 0.36 & 0.38 & 0.29 \\
\hline
\end{tabular}

Source: Own calculations based on WITS (2018) data

Table 6: The original Balassa indices calculated for Top $10 \mathrm{EU}$ dairy product exporters and VG for 2000-2017.

(RTA), revealed competitiveness (RC), LnRCA and RSCA indices. As the correlation between the indices show, there are medium or strong relationships between them (see Table 7), consequently we focus mainly on the detailed analysis of RCA.

\begin{tabular}{|l|c|c|c|c|c|}
\hline & RCA & RTA & LnRCA & RC & RSCA \\
\hline RCA & 1 & & & & \\
\hline RTA & 0.54 & 1 & & & \\
\hline LnRCA & 0.66 & 0.29 & 1 & & \\
\hline RC & 0.58 & 0.61 & 0.85 & 1 & \\
\hline RSCA & 0.79 & 0.38 & 0.92 & 0.79 & 1 \\
\hline
\end{tabular}

Source: Own calculations based on WITS (2018) data

Table 7: Correlation results of the indices.

After analysing the country level comparative advantage of selected group of the EU members, we have also examined the revealed comparative advantage of the countries on a product group level (Table 8 and 9). According to WITS database's HS6 level classification, 18 different dairy product codes belong to dairy industry. The different products have been classified into two groups based on the level of processing (low level and high level of processing).

Regarding the low processed products, we can conclude that Italy is the only country within the examined countries, which has only comparative disadvantage. Hungary performs also poorly, having a weakcomparativeadvantagein terms of milk and cream production $(=<1 \%$ fat and, $1 \%<$, but $=<6 \%$ fat products), in contrast, Austria have high $(\mathrm{RCA}=5.36)$ and medium (2.66) comparative advantage in terms of both products. Ireland is also performing similarly in terms of milk and cream in solid form products, having medium RCA results. For the rest of the countries it is valid that a given product has a relatively high comparative advantage (for example Belgium and Netherlands for sweetened milk and cream, or France and the UK for milk and cream in solid form $>1.5 \%$ ), but for the rest of the products have a weak comparative advantage or even comparative disadvantage.

In case of low processed products, we can conclude that Balassa index results are quite different and the results are independent of the fact if a given country pertains to Top 10 performers or Visegrad Group. If we examine only VG, we can conclude that Hungary has the weakest position, Slovakia has a stronger position with several comparative advantage results and finally Poland and the Czech Republic have the strongest positions in the region, having medium (in case of Poland for milk and cream in solid forms of $\leq 1.5 \%$ fat, in case of Czech Republic for milk and cream of $>1 \%$ but $\leq 6 \%$ fat, not concentrated) or weak Balassa index results for several product groups.

Regarding highly processed dairy products, the picture is more colourful, Table 9 is showing the details. One outstanding result is the very high performance of Denmark in terms of many highly processed dairy products, especially fresh cheese (6.75) and blue cheese (10.76). Ireland possesses also a very high comparative advantage (6.52) in terms of butter. Comparing the highly processed dairy products' results, it is visible that from the examined countries within this sector only the United Kingdom and Hungary have only comparative disadvantages, all other countries 


\begin{tabular}{|c|c|c|c|c|c|c|c|c|c|}
\hline Country & RCA & $\begin{array}{c}\text { Milk and } \\
\text { cream } \\
\text { of }=<1 \% \\
\text { fat, } \\
\text { not conc. }\end{array}$ & $\begin{array}{l}\text { Milk and } \\
\text { cream } \\
\text { of }>1 \% \text { but } \\
=<6 \% \text { fat, } \\
\text { not conc. }\end{array}$ & $\begin{array}{c}\text { Milk and } \\
\text { cream } \\
\text { of }>6 \% \\
\text { fat, } \\
\text { not conc. }\end{array}$ & $\begin{array}{c}\text { Milk and } \\
\text { cream in } \\
\text { solid forms } \\
\text { of }=<1.5 \% \\
\text { fat }\end{array}$ & $\begin{array}{l}\text { Milk and } \\
\text { cream } \\
\text { in solid } \\
\text { forms } \\
\text { of }>1.5 \% \\
\text { fat, uns }\end{array}$ & $\begin{array}{l}\text { Milk and } \\
\text { cream } \\
\text { in solid } \\
\text { forms } \\
\text { of }>1.5 \% \\
\text { fat, swe }\end{array}$ & $\begin{array}{l}\text { Concentrated } \\
\text { milk } \\
\text { and cream, uns }\end{array}$ & $\begin{array}{c}\text { Sweetened } \\
\text { milk } \\
\text { and cream }\end{array}$ \\
\hline Germany & 0.93 & 1.08 & 1.26 & 0.87 & 1.36 & 0.80 & 0.23 & 1.60 & 0.54 \\
\hline Netherlands & 1.19 & 0.70 & 0.74 & 1.43 & 0.85 & 1.08 & 0.60 & 1.90 & 3.00 \\
\hline France & 1.62 & 1.47 & 1.09 & 1.14 & 1.42 & 1.80 & 3.03 & 1.34 & 0.33 \\
\hline Belgium & 1.32 & 1.68 & 1.33 & 1.60 & 1.18 & 1.50 & 0.49 & 1.12 & 4.18 \\
\hline Italy & 0.54 & 0.06 & 0.02 & 0.09 & 0.12 & 0.04 & 0.03 & 0.05 & 0.07 \\
\hline Denmark & 2.24 & 0.51 & 1.27 & 1.04 & 1.06 & 1.50 & 2.23 & 0.48 & 0.16 \\
\hline Poland & 1.00 & 0.40 & 0.67 & 1.90 & 2.64 & 1.39 & 1.40 & 0.49 & 0.30 \\
\hline Ireland & 1.41 & 0.56 & 0.48 & 0.25 & 2.13 & 3.80 & 0.88 & 0.01 & 0.12 \\
\hline $\begin{array}{l}\text { United } \\
\text { Kingdom }\end{array}$ & 0.55 & 0.13 & 0.66 & 1.07 & 0.44 & 0.49 & 3.22 & 0.33 & 0.15 \\
\hline Austria & 1.20 & 5.37 & 2.66 & 0.96 & 0.26 & 1.04 & 0.64 & 0.07 & 0.15 \\
\hline $\begin{array}{l}\text { Czech } \\
\text { Republic }\end{array}$ & 0.87 & 0.63 & 2.12 & 0.71 & 1.80 & 2.26 & 1.24 & 0.44 & 1.22 \\
\hline Slovakia & 0.72 & 1.24 & 1.61 & 1.06 & 0.87 & 1.00 & 0.08 & 0.02 & 1.22 \\
\hline Hungary & 0.29 & 1.63 & 1.30 & 0.16 & 0.12 & 0.13 & 0.04 & 0.00 & 0.01 \\
\hline
\end{tabular}

Source: Own calculations based on WITS (2018) data

Table 8: The original Balassa indices calculated for low processed dairy products for EU Top10 and VG, for 2000-2017.

\begin{tabular}{|c|c|c|c|c|c|c|c|c|c|c|c|}
\hline Country & $\mathrm{RCA}$ & Yogurt & $\begin{array}{l}\text { Buttermilk, } \\
\text { curdled } \\
\text { milk and } \\
\text { cream }\end{array}$ & $\begin{array}{c}\text { Whey \& } \\
\text { modified } \\
\text { whey, } \\
\text { concentrated } \\
\text { or not }\end{array}$ & $\begin{array}{c}\text { Products } \\
\text { consisting } \\
\text { of natural } \\
\text { milk } \\
\text { constituent }\end{array}$ & $\begin{array}{l}\text { Butter } \\
\& \text { other } \\
\text { fats and } \\
\text { oils } \\
\text { derived } \\
\text { from } \\
\text { milk }\end{array}$ & $\begin{array}{c}\text { Fresh } \\
\text { (unripened } \\
\text { or } \\
\text { uncured) } \\
\text { cheese }\end{array}$ & $\begin{array}{c}\text { Grated or } \\
\text { powdered } \\
\text { cheese }\end{array}$ & $\begin{array}{l}\text { Processed } \\
\text { cheese, } \\
\text { not } \\
\text { grated or } \\
\text { powdered }\end{array}$ & $\begin{array}{l}\text { Blue- } \\
\text { veined } \\
\text { cheese }\end{array}$ & $\begin{array}{c}\text { Cheese, } \\
\text { n.e.s. }\end{array}$ \\
\hline Germany & 0.93 & 1.31 & 1.08 & 1.17 & 1.24 & 0.47 & 1.12 & 0.25 & 0.94 & 0.65 & 0.77 \\
\hline France & 1.62 & 2.28 & 2.01 & 1.69 & 2.28 & 0.69 & 1.61 & 1.54 & 1.75 & 2.07 & 1.66 \\
\hline Belgium & 1.32 & 0.69 & 2.94 & 0.35 & 0.43 & 1.91 & 0.39 & 0.78 & 2.52 & 0.15 & 0.45 \\
\hline Italy & 0.54 & 0.04 & 0.07 & 0.72 & 0.41 & 0.17 & 1.42 & 2.70 & 0.17 & 2.79 & 0.78 \\
\hline Denmark & 2.24 & 0.52 & 0.31 & 0.28 & 3.21 & 2.98 & 6.75 & 3.86 & 0.61 & 10.76 & 2.72 \\
\hline Austria & 1.20 & 3.64 & 0.54 & 1.37 & 0.64 & 0.16 & 0.78 & 0.26 & 1.97 & 0.11 & 0.92 \\
\hline $\begin{array}{l}\text { Czech } \\
\text { Republic }\end{array}$ & 0.87 & 1.24 & 0.46 & 1.01 & 0.35 & 0.61 & 0.49 & 0.04 & 0.29 & 0.23 & 0.35 \\
\hline Slovakia & 0.72 & 0.94 & 0.48 & 0.36 & 0.23 & 0.29 & 0.86 & 0.03 & 1.31 & 0.39 & 0.50 \\
\hline Hungary & 0.29 & 0.15 & 0.21 & 0.27 & 0.45 & 0.04 & 0.08 & 0.01 & 0.48 & 0.00 & 0.08 \\
\hline
\end{tabular}

Source: Own calculations based on WITS (2018) data

Table 9: The original Balassa indices calculated for highly processed dairy products for EU Top 10 and VG, for 2000-2017.

have at least one product where the country has the highest comparative advantage result. The other three VG countries (Poland, Czech Republic and Slovakia) are also performing modestly having only 3-2-1 weak comparative advantages in case of highly processed dairy products respectively.
It is also visible that for given product types only a few countries have relatively high comparative advantages (for example sweetened milk and cream, blue cheese or butter), but for the performance for rest of the countries is showing comparative disadvantage. 


\section{Discussion}

The comparative advantages of the European Union and the Visegrad Group have revealed a number of important phenomena already discussed in the literature.

The European Union supplies one-quarter of the world's dairy production and adds $30 \%$ of its commercial growth, mainly with highly processed products (cheese, milk powder, butter). Behind this, the main competitors have been able to increase their production to a greater extent, so European countries are entering the market with highly processed products. In addition, they can devote significant resources to product innovation and technology development (Tacken et al., 2009; Lemoine, 2016; Jansik et al., 2014). A significant part of EU dairy production is realized in Germany and in the Baltic Sea countries, with a production volume of $37.4 \%$, and $31.4 \%$ of sales in 2012 (Jansik et al., 2014). $42 \%$ to $43 \%$ of the world's cheese production is linked to the European Union, which is the market leader in the world, as it was proved by the strong comparative advantage indices in Denmark, Italy and the Netherlands. The share of EU products in other segments is declining due to the dynamically growing dairy production in developing countries (Tacken et al., 2009). The ending of the milk quota system favoured the more competitive countries because they could export their surplus on a good price. In VG countries the elimination of milk quotas together with the Russian embargo and the cheap import products, resulted in price drop and decreasing competitiveness (Zdráhal et al. 2016; Hanisch et al. 2013). In contrast, Polish dairy sector was able to develop the technology and increase the milk production per animal as well as its effectiveness. The results of analyses based on statistical data are also consistent with the literature.

Jansik et al., (2014) and Viira et al. (2015) identified industry structure, the number, size and geographical distribution of competitors, the level of ownership structure and the cost of production resources as main determinants of competitiveness in the dairy sector. The examples of France, Germany and Poland prove that strong internal demand for the dairy products can be a basis of export success. Poland, however contradicts the above-mentioned competitiveness factors: its dairy sector is fragmented, $95 \%$ of milk is produced in family farms, concentration is low, while technology is developing. In Poland's case, low level of concentration and fragmented ownership do not impede export success. However, in Slovakia and Hungary the dominance of foreignowned milk production and processing, the more concentrated industry and the FDI flowed into the sector during the transition period do not result in export success. The geographically close, big markets (e.g. Germany) are advantageous for the Polish and Czech dairy producers, as it can be seen in their export volume.

To be able to save or improve market positions, VG countries need to develop their competitiveness and join forces (Zdráhal et al., 2018). It might worth to study and benchmark such success stories like those of the Baltic countries which were able to build up comparative advantages, as well as make deep market analyses to understand the specialities, needs and customer expectation of VG region.

\section{Conclusions}

In order to ensure the stable development of milk processing in the coming years and to serve the higher growth in developing countries, dairy companies should be prepared to increase their capacities. Increasing customer expectations on the market also mean that products are highly processed, and our results show that highly processed products are key to competitiveness.

The study can be concluded with a number of useful, forward-looking, thought-provoking conclusions.

On the one hand, when examining the export of milk and dairy products in the European Union, it was found that large quantities of milk production did not clearly lead to the export market success of the country concerned. Germany, France and the United Kingdom have been identified as the largest milk producing countries in the EU, but Denmark, Ireland and France have been the most successful in exports, based on the Balassa index calculations. Even more surprisingly, large dairy countries do not have a really strong comparative advantage in the export of dairy products, only either weak or medium. On the other hand, we have discovered that some countries have a really strong, dominant competitive advantage for highly processed products, which confirms the literature's view that the industry is developing towards these products, which can be the key of success in international trade. Thirdly, we have shown that there are not any strong, dominant country in the export of low-processed dairy products, such as, for example in the case of highly processed products (Denmark - blue cheese, fresh cheese; Ireland - butter). This suggests that countries 
specialize for the production of a product which is then admitted by the market. For the Visegrad Group, which is able to make a small contribution to European milk production and exports (except Poland), this pattern can be followed. In this context, we can outline further research directions in which we plan to continue our research activities. One direction can be the identification of products which on comparative advantage could be built in the different VG countries. Another direction could be the discovery of the possibilities of digital technologies in increasing production and processing efficiency.

As all the researches have, this analysis has also a few limitations. The first two are more related to the database, the third and the fourth are more related to the index itself. The first limitation is that the data derived is not totally reliable because disaggregated values might not add up, missing values problem exists; data change by classification and export and respective import values for the same destination might not match. The second limitation of the research is that cleaning of the database could cause the loss of useful information. The third limitation is that the calculated competitiveness indices are sensitive to zero and extreme values. The fourth limitation is that due to correlation results of the calculated indices and extent of the paper we focus on the analysis of the original Balassa index. In spite of all these limitations, a useful analysis has been carried out with meaningful results.

\section{Acknowledgements}

This publication has been supported by the European Union and Hungary and co-financed by the European Social Fund through the project EFOP-3.6.3VEKOP-16-2017-00007, titled "Young researchers from talented students - Fostering scientific careers in higher education".

Corresponding authors

Judit Nagy, PhD., associate professor,

Corvinus University of Budapest, 8 Fövám tér, 1093 Budapest, Hungary

Phone: +361482 5232,E-mail: judit.nagy@uni-corvinus.hu

\section{References}

[1] Bakucs, L. Z., Fałkowski, J. and Ferto, I. (2012) "Does Farm and Processing Industry Structure Matter for Price Transmission? Some Evidence From Transition Countries: A Comparison of Dairy Sectors in Hungary and Poland”. IEHAS Discussion Papers No. MT-DP-2012/12.

[2] Balassa, B. (1965) "Trade Liberalization and Revealed Comparative Advantage", The Manchester School, Vol. 33, pp. 99-123. ISSN 1463-6786. DOI 10.1111/j.1467-9957.1965.tb00050.x.

[3] Bojnec, S. and Ferto, I. (2014) "Export competitiveness of dairy products on global markets: The case of the European Union countries", Journal of Dairy Science, Vol. 97, No. 10, pp. 6151-6163. ISSN 1525-3198. DOI 10.3168/jds.2013-7711.

[4] Bristow, G. (2005) "Everyone's a 'winner': problematising the discourse of regional competitiveness", Journal of Economic Geography, Vol. 5, No. 3, pp. 285-304. ISSN 1468-2702. DOI 10.1093/jeg/lbh063.

[5] Buckley, P. J., Pass, C. L. and Prescott, K. (1988) "Measures of international competitiveness: a critical survey", Journal of Marketing Management, Vol. 4, No. 2, pp. 175-200. ISSN 0267-257X. DOI 10.1080/0267257X.1988.9964068.

[6] Budd, L. and Hirmis, A. (2004) "Conceptual framework for regional competitiveness", Regional Studies, Vol. 38, No. 9, pp. 1015-1028. ISSN 0034-3404. DOI 10.1080/0034340042000292610.

[7] Čechura, L., Žáková Kroupová, Z. and Hockmann, H. (2015) "Market Power in the European Dairy Industry“, AGRIS on-line Papers in Economics and Informatics, Vol. 7, No. 4, pp. 39-47. ISSN 1804-1930. DOI 10.7160/aol.2015.070404.

[8] Chikan, A. (2008) "National and firm competitiveness: a general research model", Competitiveness Review, Vol. 18, No. 1-2, pp. 20-28. ISSN 1059-5422. DOI 10.1108/10595420810874583. 
[9] Dalum, B., Laursen, K. and Villumsen, G. (1998) "Structural Change in OECD Export Specialisation Patterns: de-specialisation and 'stickiness'", International Review of Applied Economics, Vol. 12, No. 3, pp. 423-443. ISSN 0269-2171. DOI 10.1080/02692179800000017.

[10] Domazet, T. (2012) "Regional cooperation striving for competitiveness and finance", Ekonomika Preduzé́a, Vol. 60, No. 5-6, pp. 290-300. ISSN 0353-443x. DOI 10.5937/ekopre1206290D.

[11] European Committee (2017) "EU agricultural outlook for the agricultural markets and income, 2017-2030". [Online]. Available: https:/ec.europa.eu/agriculture/markets-and-prices/mediumterm-outlook_en [Accessed: 12 Oct. 2018].

[12] European Committee (2018) "Short-term Outlook for EU agricultural markets in 2018 and 2019." [Online]. Available: https://ec.europa.eu/agriculture/markets-and-prices/short-term-outlook_en [Accessed: 12 Oct. 2018].

[13] Eurostat (2017) [Online]. Available: https://ec.europa.eu/eurostat/statistics-explained/index. php?title=Milk_and_milk_product_statistics [Accessed: 9 Jan. 2019].

[14] Fałkowski, J. (2012) "Vertical coordination, access to capital, and producer loyalty in the Polish dairy sector", Agricultural Economics, Vol. 43, No. 2, pp. 155-164. ISSN 0169-5150. DOI 10.1111/j.1574-0862.2011.00573.x.

[15] Gorton, M., Hubbard, C. and Ferto, I. (2013) "Theoretical background and conceptual framework", Halle: Leibniz Institute of Agricultural Development in Transition Economies (IAMO), Working paper, pp. 1-48.

[16] Hanisch, M., Rommel, J. and Müller, M. (2013) "The cooperative yardstick revisited: panel evidence from the European dairy sectors”, Journal of Agricultural \& Food Industrial Organization, Vol. 11, No. 1, pp. 151-162. ISSN 1542-0485. DOI 10.1515/jafio-2013-0015.

[17] Hinloopen, J. and van Marrewijk, C. (2001) "On the empirical distribution of the Balassa Index", Review of World Economics, Vol. 137, No. 1, pp. 1-35. ISSN 1610-2878. DOI 10.1007/BF02707598.

[18] Jansik, C. (2009) "A comparison of dairy supply chains in Finland and in the Baltic Countries", IAMA Symposium.

[19] Jansik, C., Irz, X. and Kuosmanen, N. (2014) "Competitiveness of Northern European dairy chains", [Online]. Available: https://portal.mtt.fi/portal/page/portal/mtt/mtt/julkaisut/Dairy\%20chain $\% 20$ competitiveness\%20MTT\%202014\%20final\%20version.pdf [Accessed: 12 Oct. 2018].

[20] Kiss, J. (2007) "The impact of EU accession on the agricultural trade of the Visegrád countries", Hungarian Statistics Review, special number 11, pp. 93-116. ISSN 0039-0690.

[21] Kitson, M., Martin, R. and Tyler, P. (2004) "Regional Competitiveness: An Elusive yet Key Concept?”, Regional Studies, Vol. 38, No. 9, pp. 991-999. ISSN 0034-3404. DOI 10.1080/0034340042000320816.

[22] Kubicova, L., Kadekova, Z. and Dobak, D. (2014) "Trends in consumption of milk and dairy products in Slovakia after EU accession", Polityki Europejskie, Finanse i Marketing, Vol. 12, No. 61, pp. 90-97. ISSN 2081-3430.

[23] Laursen, K. (2015) "Revealed comparative advantage and the alternatives as measures of international specialization", Eurasian Business Review, Vol. 5, No. 1. pp. 99-115. ISSN 2147-4281. DOI 10.1007/s40821-015-0017-1.

[24] Leishman, D., Menkhaus, D. J. and Whipple, G. D. (2000) "Revealed comparative advantage and the measurement of international competitiveness for wool", Sheep \& Goat Research Journal, Vol. 16, No. 2, pp. 58-64.

[25] Lemoine, R. (2016) "European dairy sector rising to all challenges", Revue Laitière Française, No. 767, pp. 1-8.

[26] OECD-FAO (2018) “OECD-FAO Agricultural Outlook 2018-2027", OECD Publishing, Paris/Food and Agriculture Organization of the United Nations, Rome. DOI 10.1787/agr_outlook-2018-en. 
[27] Perekhozhuk, O., Hockmann, H., Ferto, I. and Bakucs, L. Z. (2013) "Identification of market power in the Hungarian dairy industry: A plant-level analysis", Journal of Agricultural \& Food Industrial Organization, Vol. 11, No. 1, pp. 1-13. ISSN 1542-0485. DOI 10.1515/jafio-2012-0005.

[28] Poppe, K. J. (2008) "Regulation and competitiveness in the European dairy industry", [Online]. Available: https://ec.europa.eu/docsroom/documents/3363/attachments/1/translations/en/renditions/ pdf [Accessed: 12 Oct. 2018].

[29] Porter, M.E. (1990) "Competitive advantage of nations", Harvard Business Review, Vol. 68, No. 2, pp. 73-93. ISSN 0017-8012.

[30] Ricardo, D. (1817) "On the principles of political economy and taxation", New York: Macmillan, 1909.

[31] Salou, T., van der Werf, H. M., Levert, F., Forslund, A., Hercule, J. and Le Mouël, C. (2017) "Could EU dairy quota removal favour some dairy production systems over others? The case of French dairy production systems", Agricultural Systems, Vol. 153, No. May 2017, pp. 1-10. ISSN 0308-521X. DOI 10.1016/j.agsy.2017.01.004.

[32] Saricoban, K. and Kaya, E. (2017) "Determination of the seafood export competitiveness: the comparative analysis of top ten countries having lion share from seafood export", Journal of Business, Economics and Finance, Vol. 6, No. 2, pp. 112-124. ISSN 2146-7943. DOI 10.17261/Pressacademia.2017.500.

[33] Spicka, J. (2013) "The Competitive Environment in the Dairy Industry and its Impact on the Food Industry", AGRIS On-Line Papers in Economics and Informatics, Vol. 5, No. 2, pp. 89-102. ISSN 1804-1930.

[34] Spicka, J., Smutka, L. and Selby, R. (2015) "Recent areas of innovation activities in the Czech dairy industry", Agricultural Economics, Vol. 61, No. 6, pp. 249-264. ISSN 0139-570X. DOI 10.17221/128/2014-AGRICECON.

[35] Tacken, G. M. L., Batowska, A., Gardebroek, C., Turi, K. N., Banse, M., Wijnands, J. H. M. and Poppe, K. (2009) "Competitiveness of the EU dairy industry". [Online]. Available: http://edepot.wur.nl/10766 [Accessed: 12 Oct. 2018].

[36] Torok, A., Mizik, T. and Jambor, A. (2018) "The Competitiveness of Global Coffee Trade", International Journal of Economics and Financial Issues, Vol. 8, No. 5, pp. 1-6. ISSN 2146-4138.

[37] Viira, A. H., Omel, R., Värnik, R., Luik, H., Maasing, B. and Põldaru, R. (2015) "Competitiveness of the Estonian dairy sector, 1994-2014”, Journal of Agricultural Science, Vol. 26, No. 2, pp. 84-105. ISSN 1469-5146.

[38] Vollrath, T. L. (1991) "A theoretical evaluation of alternative trade intensity measures of revealed comparative advantage", Weltwirtschaftliches Archiv, Vol. 130, No. 2, pp. 263-279. ISSN 1610-2878. DOI 10.1007/BF02707986.

[39] Wijnands, J. H. M., Bremmers, H. J., van Der Meulen, M. and Poppe, K. J. (2008) "An economic and legal assessment of the EU food industry's competitiveness", Agribusiness, Vol. 24, No. 4, pp. 417-439. ISSN 0742-4477. DOI 10.1002/agr.20167.

[40] World Integrated Trade Solution (WITS) database (2018) World bank. Open databases. [Online]. Available: https://wits.worldbank.org/ [Accessed: 5 Oct. 2018].

[41] Zdráhal, I., Chmelíková, G., Blažková, I. and Bečvářová, V. (2016) "Differences in the Performance of the Dairy Industries within the Visegrad Group Countries", The International Scientific Conference INPROFORUM 2016, November 3-4, 2016, České Budějovice, 132-136 p.

[42] Zdráhal, I., Chmelíková, G. and Blažková, I. (2018) "Sector-Wide and Country-Specific Drivers of Firm Performance in the Visegrad Group Dairy Industry", AGRIS on-line Papers in Economics and Informatics, Vol. 10, No. 4, pp. 89-100. ISSN 1804-1930. DOI 10.7160/aol.2018.100410. 


\section{Appendix}

\begin{tabular}{|l|l|}
\hline Product code & Descriptions \\
\hline 40110 & Milk and cream of $=<1 \%$ fat, not concentrated \\
\hline 40120 & Milk and cream of $>1 \%$ but $=<6 \%$ fat, not concentrated \\
\hline 40130 & Milk and cream of $>6 \%$ fat, not concentrated \\
\hline 40210 & Milk and cream in solid forms of $=<1.5 \%$ fat \\
\hline 40221 & Milk and cream in solid forms of $>1.5 \%$ fat, unsweetened \\
\hline 40229 & Milk and cream in solid forms of $>1.5 \%$ fat, sweetened \\
\hline 40291 & Concentrated milk and cream, unsweetened \\
\hline 40299 & Sweetened milk and cream (excl. in solid form) \\
\hline 40310 & Yogurt \\
\hline 40390 & Buttermilk, curdled milk and cream \\
\hline 40410 & Whey \& modified whey concentrated or not \\
\hline 40490 & Products consisting of natural milk constituent \\
\hline 40500 & Butter \& other fats and oils derived from milk \\
\hline 40610 & Fresh (unripened or uncured) cheese \\
\hline 40620 & Grated or powdered cheese \\
\hline 40630 & Processed cheese not grated or powdered \\
\hline 40640 & Blue-veined cheese \\
\hline 40690 & Cheese (not elsewhere specified) \\
\hline
\end{tabular}

